\title{
THE EFFECT OF DOMINANT SPECIES ON NUMBERS AND AGE STRUCTURE OF IRIS SIBIRICA L. POPULATION ON BLUE MOOR-GRASS MEADOW IN SOUTHERN POLAND
}

\author{
KINGA KOSTRAKIEWICZ \\ Department of Plant Ecology, Institute of Botany, Jagiellonian University \\ Lubicz 46, 31-512 Kraków, Poland \\ e-mail: kostrakiewicz@ib.uj.edu.pl
}

(Received: June 14, 2006. Accepted: September 27, 2006)

\begin{abstract}
Two populations of Iris sibirica, a clonal species protected by law in Poland, occurring in patches of Molinietum caeruleae, of similar floristic composition although with different dominant species, were studied. In the Stanisławice locality, species with a high competitive potential prevailed, contrary to the Opatkowice locality, where the species of low competitive potential dominated. It was established that vegetative propagation ensures the continued presence of populations in both localities, although the proximity of plants with high competitive potential limits the vegetative propagation of ramet clusters of Iris sibirica. Despite the high level of seed production, the recruitment of seedlings in both patches is possible only in artificially created gaps. The field observations support the conclusion that creating gaps allowing for germination of seeds and development of seedlings, as well as eliminating expansive neighbours allowing proliferation of ramet clusters of Iris sibirica, is an affective way of protecting populations of this species.
\end{abstract}

KEY WORDS: clonal plant, seedling recruitment, vegetative reproduction, generative reproduction.

\section{INTRODUCTION}

The occurrence of different species within a small space involves their interactions, including the competition for light, water and mineral compounds. As a result of such competition, the populations of the same species occurring in different communities may be characterised by different patterns of population dynamics. These patterns were first noted for aclonal plants, which represented a more convenient subject for studies, because of their unitary growth pattern, short life span, and solely generative manner of reproduction (e.g.. Wilkoń-Michalska 1976; Watkinson and Harper 1978; Symonides 1979a, 1979b, 1979c; Law 1981, Falińska and Pirożnikow 1983; Watkinson and Davy 1985). Much less known is the population number dynamics in clonal species, with a multi-shoot architecture of individuals, longevity, as well as propagation of both generative and vegetative ways (cf. Falińska 1986, 1995; Czarnecka 1989; Cain and Damman 1997; Brzosko 2001).

Studies carried out on the populations of clonal plants revealed the great variability in the dynamics of their populations in different communities. The diversified reproduction and mortality rates, which determine the age structure, were observed, in the populations of Carex cespitosa, Filipendula ulmaria, Iris pseudacorus, Maianthemum bifolium, M. dilatatum, and Serratula tinctoria (Falińska 1986, 1995, 2003; Czarnecka 1989; Brzosko 2001; Lezberg et al. 2001;
Bissels et al. 2004). Despite the growing interest in population biology of clonal plants, the current level of knowledge is still inadequate. It holds particularly with respect to rare and protected species. The studies that take into account the effect of neighbouring plants, and particularly dominant species, on the population dynamics of endangered taxa, can provide a basis for effective protection programmes.

In Poland, one of the rare and strictly protected clonal plants is Iris sibirica, a species which belongs to Euro-Siberian sub-element. The greatest numbers of localities of this taxon occur in Lower Silesia, the Lublin upland and Roztocze, whereas the lowest numbers are recorded in the Baltic coastal area and western Pomorze (Pomerania) (Zając and Zając 1997). The populations of Iris sibirica occur in various plant communities. They are found in flood plain forests of the alliance Alno-Ulmion, oak-hornbeam woods (Tilio-Carpinetum), oak woods (Potentillo albae-Quercetum), pine forests (Pino-Quercetum) and pine forests with moor grass (Molinio-Pinetum). They were also recorded in macroforb community (Filipendulo-Geranietum), as well as in matt-grass communities (Nardo-Juncetum squarosi). However, the populations of this species are found most often in moor-grass meadows (Molinietum caeruleae) (Kostrakiewicz 2001, 2004).

Iris sibirica is a long-living clonal plant, with numerous leaf rosettes and flowering shoots, connected by permanent 
rhizomes with short internodes. It is characterised by the iterative growth of genets resulting from processes of dying, regeneration and proliferation occurring at variable intensities in subsequent stages of development. Iris sibirica reproduces in generative and vegetative manner. Vegetative reproduction consists of the proliferation and fragmentation of individuals (cf. Klimeš et al. 1997; Klimeš and Klimešowa 1999). The main objectives of this study were to learn: (1) how the individual development of genets in Iris sibirica occur (2) how important is the vegetative reproduction to the preservation of this rare species, (3) whether generative reproduction is possible, and if so, under what conditions it occurs, (4) what are the effects of these two manners of propagation on the population number and structure, and (5) how to protect the populations of this taxon.

\section{STUDY AREA}

The studies were carried out in two localities in southern Poland. These were Stanisławice (49 $58^{\prime}$ N, 20 22' E) in the Podgórze Bocheńskie foreland at the elevation of 199.5 $\mathrm{m}$ a.s.1., and Opatkowice $\left(50^{\circ} 04^{\prime} \mathrm{N}, 19^{\circ} 50^{\prime} \mathrm{E}\right)$ situated in the southern part of Kraków, at 234 m a.s.1.

The patches of Molinietum caeruleae occurring in these localities are remnants of once vast meadows, which existed along the Vistula River from Czernichów to the Niepołomice Primeval Forest (Zarzycki 1956, 1958). The flora and plant communities of the moor grass meadows in Opatkowice were studied earlier by Dubiel $(1991,1996)$. The location of Iris sibirica in Stanisławice has been described only relatively recently (Kostrakiewicz 2000). The patches of Molinietum caeruleae in the study area are characterised by the presence of a large number of rare and protected species, such as: Dianthus superbus, Gentiana pneumonanthe, Gladiolus imbricatus, Trollius europaeus and Orchis latifolia. Unfortunately, the communities of this type are rapidly disappearing. The International Union for the Conservation of Nature (ICUN) has listed them among the most endangered plant communities in Europe (Denisiuk 1991). Among the factors affecting their elimination are drainage practices and extensive management. When the cutting of meadows ceases, shrub vegetation is allowed to invade, which in turn brings about rapid changes in the herb layer of these meadows (Barabasz 1998; Denisiuk 1965, 1987; Kostrakiewicz 2000, 2001).

The moor-grass meadows where this study was conducted had not been managed for at least a dozen years. The information obtained from interviewing local residents indicates that a patch in Stanisławice had not been cut or grazed for just such a period. The patch in Opatkowice has not been used since at least 1995 (Denisiuk et al. 1995). Both patches have a similar floristic composition, but differ in respect of the dominant species (whose coverage exceeds $50 \%$ ). In Stanisławice, these are tall perennial plants with fleshy and deeply rooted rhizomes and perennials forming large compact tussocks. According to Grime's classification (Hunt et al. 2004) these species are characterised by C-type strategies (Phragmites australis, Chamanerion angustifolium, Epilobium hirsutum), C/CSR (Lythrym salicaria), C/SC (Juncus conglomeratus), CSR (Valeriana officinalis), and SC-type strategies (Molinia carulaea). In the Opatko- wice site prevailed plants of a less competitive potential. The dominant species there were some small-tussock species, or others with delicate, shallowly rooted rhizomes or stolons, which were either strategists of an S-type (Briza media), S/CSR (Lotus corniculatus), CSR (Lathyrus pratensis, Lychnis flos-cucculi, Holcus lanatus) or a CS/CRStype (Galium verum).

\section{MATERIAL AND METHODS}

The studies were carried out during the period 1999-2002. A genet and a cluster of ramets were adopted as the basic demographic units. A genet (genetic individual) is a plant which, despite its multiplication, emerged from a single zygote. The term "genet" was applied to plants in the earlier stages of development (initial, juvenile, or early generative), because only at these stages could it be established for sure that they had developed from the same zygote. As regards plants in the later stages (generative, senile, or fragmentation), these were referred to as clusters of ramets, meaning an aggregation of generative shoots and rosettes formed in the course of vegetative proliferation of a genet or genets. The cluster of ramets may therefore, be either a genet or a group of independent units emerging as a results of the fragmentation of a genet or fragmentation of several genets. The term ramet denotes a single rosette of leaves or a generative shoot.

In 2000, the Stanisławice population consisted of 502 clusters of ramets and covered $5600 \mathrm{~m}^{2}$, whereas the Opatkowice population consisted of 26 ramets covering 1800 $\mathrm{m}^{2}$. In order to study the individual development genets in Iris sibirica, a morphological analysis was performed with respect to individuals grown in experimental gardens and those growing in the wild. In 1999, in the experimental garden, 50 seeds were planted on each of six plots, and the observation of genets was observed throughout the first three years of their lives. Each year, 3 or four well-grown individuals were removed and their morphological structure analysed. In the year 2000, 10 older genets were dug up from the field locations. This small number of collected genets reflected the need to protect the local populations of Iris sibirica. After the underground parts were dissected, the ages of the plants were determined by analysing the annual increments of rhizome segments (cf. Łukasiewicz 1966), assuming that in a single year only one the rhizome segment develops - as reported by Kirchner (1934). In genets collected from the experimental garden and from natural locations, the leaf rosettes and generative shoots were counted. The surface of the genets was measured at the ground part, in the widest and narrowest places, along perpendicular lines. On the basis of this information, the age stage of each individual was determined. The age stage identification followed the classification proposed by Falińska (1986, 1995). This author determined these classes by analysing the individual growth of Iris pseudacorus and Filipendula ulmaria genets, which show the same architecture and growth strategy as Iris sibirica.

The effectiveness of the vegetative reproduction was estimated by the increases in the number of above ground units, the surface area of the genets, and the ramet clusters. In the year 2000, ten genets in the initial stage of development, and growing in the experimental garden were selec- 
ted and marked, and their continuing development monitored throughout 2001 and 2002. At the same time, 5 clusters of ramets were selected and marked at each of the various stages: generative, senile and fragmentation. Every year, the rosettes and generative shoots were counted, and the areas of the clusters of ramets were measured. The statistical analysis applied the Student t-test for tied pairs.

The effectiveness of the generative reproduction was estimated on the basis of a number of seeds produced by particular clusters of ramets in the whole population, and on the recruitment and survivability of the seedlings. The number of seeds produced by a cluster of ramets was estimated by multiplying the number of capsules in a given cluster by the average number of seeds calculated for 50 selected ramets. The statistical analysis of differences in the number of seeds produced in different stages, populations and years was performed using the Mann-Whitney U test.

The recruitment of seedlings was studied in a fully compact herb layer and in experimentally created gaps. In order to assess this, in the year 2000, 6 plots of $1 \mathrm{~m}^{2}$ size were randomly selected in each of the two studied meadow patches. In three plots, all vegetation cover and litter was removed except for the ramet clusters of Iris sibirica present in situ. The remaining plots were left untouched. From the clusters of ramets occurring in the plots, all seeds were removed and counted before being sown on the same plots. The fate of the seedlings was monitored throughout the next two vegetation seasons. In 2001 and 2002, all capsules formed by individuals growing in the plots were removed, to eliminate recruitment from the then germinating seeds.

In order to determine the changes in population numbers and age structures in the period 2000-2002, the genets and clusters of ramets were counted and their age stage established in squares of $100 \mathrm{~m}^{2}$ size on sites occupied by the studied populations.

\section{RESULTS}

\section{Growth and development of the genets of Iris sibirica}

Six developmental stages of Iris sibirica were distinguished: seedlings, juvenile, early generative, generative, senile and the fragmentation stage (Table 1). The observations carried out in the experimental garden showed that the seedlings appear throughout summer till late autumn, from seed sown in the previous year (Fig. 1). Near the end of the first season, the genets consist of a single leaf rosette with a small root system, and their area ranges from 0.15 to $0.25 \mathrm{~cm}^{2}$. In the second year of life the individuals move into the juvenile stage (Fig. 2). At this stage, they have several leaf rosettes and occupy an area of 1 to $2 \mathrm{~cm}^{2}$. The early generative stage appears during the third year of life, when the genets are formed by more than ten rosettes and one or two flowering shoots (Fig. 3). During the observations in natural conditions, it was found that the generative stage continues from the fourth till the seventh year of life. At this stage, the genets have distinctly developed stolons and large numbers of rosettes and generative shoots. The studied individuals had from between 60 to 160 rosettes and 7 to 26 generative shoots. The area of the genets ranged from between 110 and $513 \mathrm{~cm}^{2}$. The senile stage lasts from the eighth till the tenth year of life and is characterised by advancing senility of the oldest sections of the rhizomes. Genets then form rings with gradually increasing "empty centre", i.e. without shoots or rosettes, located in the middle of organism. The individuals at this stage, collected in the field, contained a number of rosettes ranging from 141 to 238 , and from 11 to 18 generative shoots. They occupied an area of 650 to $1100 \mathrm{~cm}^{2}$. After the tenth year of age, the fragmentation stage occurs. At this stage no flowering shoots appear and rosettes form aggregations separated by senile rhizomes. The ageing processes prevail over regeneration, leading on to the death of an individual, or its oldest parts, but most often to its splitting into several parts. In the specimens observed, the number of leaf rosettes ranged from 216 to 225 , and the area - from 1230 to $1380 \mathrm{~cm}^{2}$.

\section{Dynamics of the studied populations}

The vegetative reproduction in Iris sibirica consists of the proliferation of individuals followed by their fragmentation. The proliferation of the genets and the clusters of ramet resulted in increasing numbers of leaf rosettes and generative shoots. The highest effectiveness of vegetative propagation was observed in the early age stages. At the juvenile and early generative stages, a severalfold increase in the numbers of above-ground parts and their surface areas occurred (Table 2). In the later life stages, the effectiveness of the vegetative reproduction had gradually decreased (Table 3). In two years in the ramet clusters at the generative stage, the number of ramets increased on average

TABLE 1. Characteristics of developmental stages of Iris sibirica on the basis of chosen genets. The developmental stages: S. - seedlings; JUW. - juvenile; E. GEN. - early generative; GEN. - generative; SEN. - senile; FRAG. - fragmentation. If more than 1 genet was studied the average value was set.

\begin{tabular}{|c|c|c|c|c|c|c|}
\hline Site & $\begin{array}{c}\text { Developmental } \\
\text { stage }\end{array}$ & Age (years) & $\begin{array}{l}\text { Number } \\
\text { of genets }\end{array}$ & $\begin{array}{l}\text { Number } \\
\text { of rosettes }\end{array}$ & $\begin{array}{c}\text { Number } \\
\text { of generative shoots }\end{array}$ & $\begin{array}{l}\text { Area of genets } \\
\qquad\left(\mathrm{cm}^{2}\right)\end{array}$ \\
\hline \multirow[t]{3}{*}{ Experimental garden } & S. & 1 & 3 & 1 & - & 0.2 \\
\hline & JUW. & 2 & 3 & 5.0 & - & 1.5 \\
\hline & W. GEN & 3 & 4 & 13.2 & 1.5 & 8.6 \\
\hline \multirow[t]{8}{*}{ Natural locality } & GEN & 4 & 1 & 60 & 7 & 110 \\
\hline & GEN & 6 & 2 & 102.0 & 15.0 & 307.5 \\
\hline & GEN & 7 & 1 & 152 & 25 & 513 \\
\hline & SEN & 8 & 1 & 141 & 12 & 650 \\
\hline & SEN & 9 & 2 & 173.6 & 16.8 & 1046.0 \\
\hline & SEN & 10 & 1 & 238 & 8 & 1100 \\
\hline & FRAG & 12 & 1 & 216 & - & 1380 \\
\hline & FRAG & 13 & 1 & 225 & - & 1230 \\
\hline
\end{tabular}




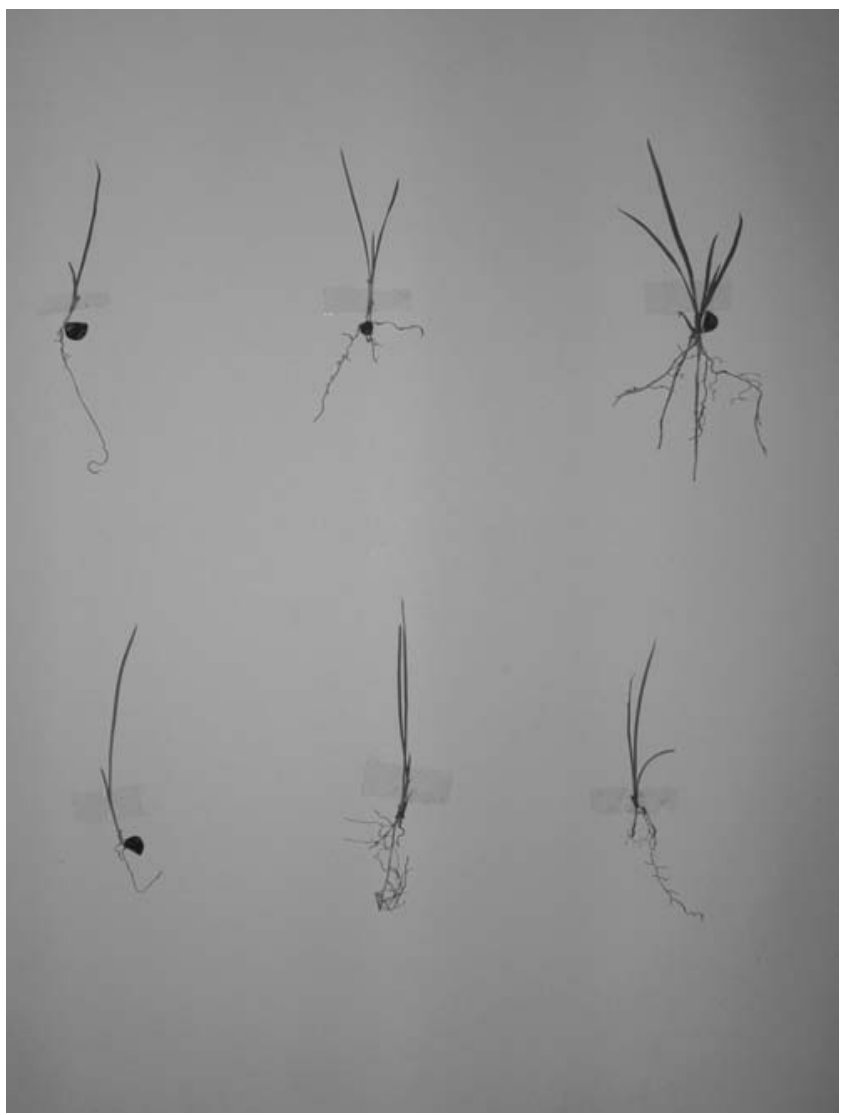

Fig. 1. Genet in initial stage.

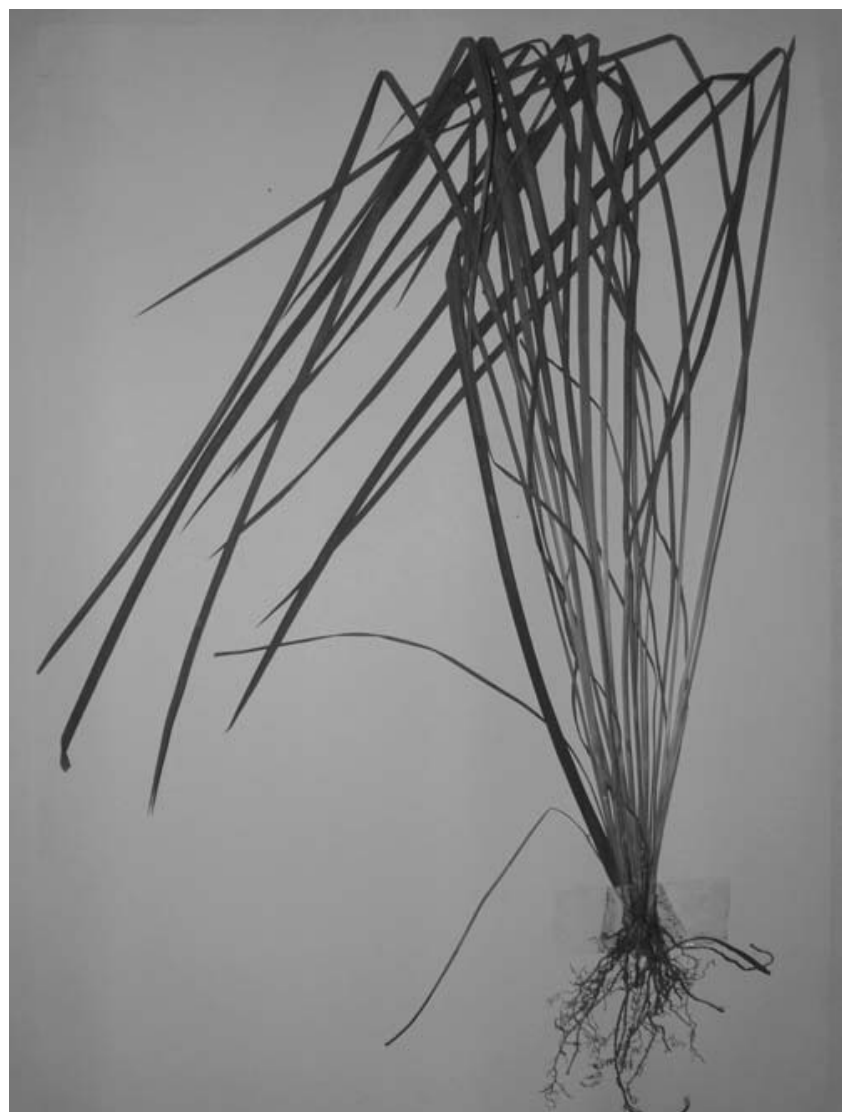

Fig. 2. Genet in juvenile stage.

by $60.4(66.8 \%)$ in Opatkowice, and by $55.6(64.2 \%)$ in Stanisławice. The area occupied by clusters increased in Opatkowice on average by $232.4 \mathrm{~cm}^{2}(93.3 \%)$, while in Stanisławice - by $105.0 \mathrm{~cm}^{2}(48.5 \%)$. In the clusters of ra-

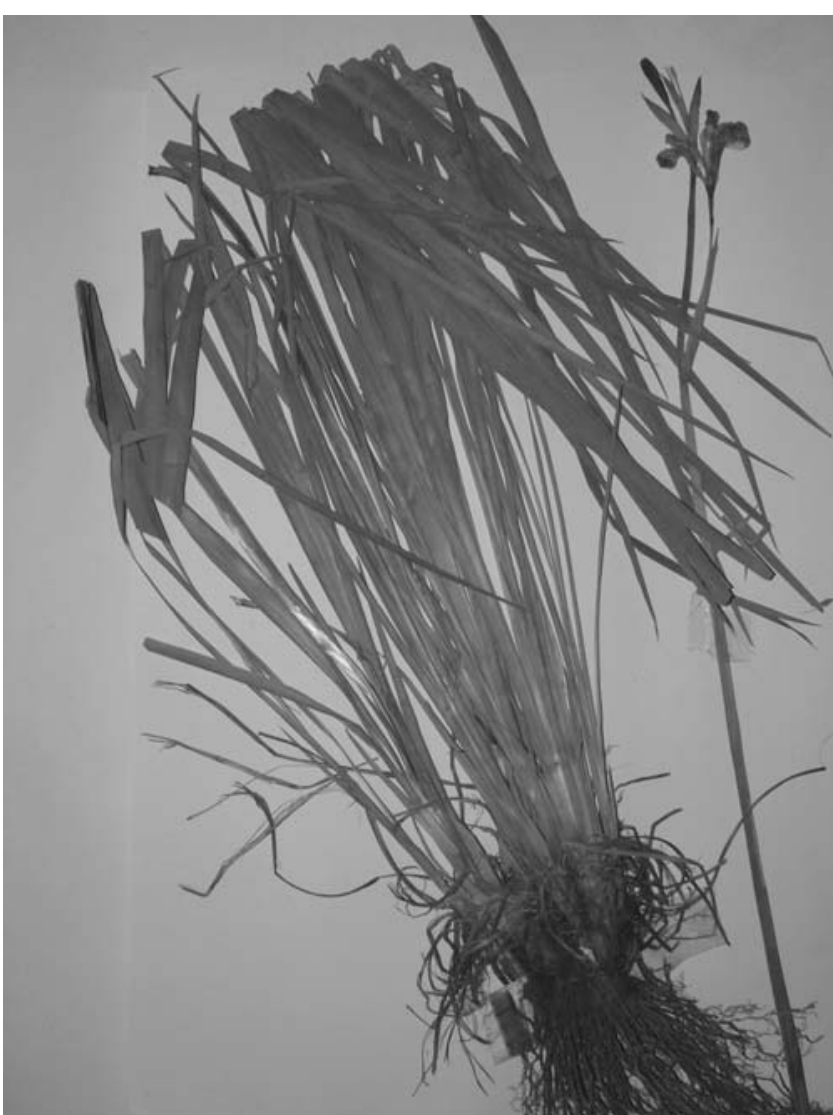

Fig. 3. Genet in early generative stage.

mets at the senile stage, the average number of rosettes and flowering shoots increased by $55.0(33.0 \%)$ in Opatkowice, whereas in Stanisławice - by $38.4(21.70 \%)$. The area occupied by ramet clusters in Opatkowice increased by $292.8 \mathrm{~cm}^{2}(37.0 \%)$, whereas in Stanisławice - it was by $171.0 \mathrm{~cm}^{2}(22.3 \%)$. In the fragmentation stage, the number of above-ground units decreased. In Opatkowice, the average decrease was 14.6 (6.4\%), whereas in Stanisławice it was $18.0(7.8 \%)$. At this stage the area occupied by ramet clusters increased slightly: in Opatkowice - by an average $49.2 \mathrm{~cm}^{2}(3.8 \%)$, whereas in Stanisławice - by 35.8 $\mathrm{cm}^{2}(2.8 \%)$.

The increase in population numbers of Iris sibirica may also have been brought about by the generative reproduction in ramet clusters at the early generative, generative and senile stages. At the early generative state, the presence of genets was not detected in any of the studied population. In both populations more seeds were produced by the ramet clusters in the generative stage than in senile stage (Table 4). More seeds were produced by the ramet clusters in the communities with plants of high competitive potential (Stanisławice), than in those living amidst weaker competitors (Opatkowice). Both generative and senile clusters of ramets produced the least quantities of seeds in 2001, with moderate numbers in 2000 , and the highest numbers of seeds in 2002. In both populations, the differences occurring in seed production were statistically significant.

Despite remarkable individual fertilities, no recruitment of seedlings were recorded in a fully compact herb layer, whilst similar numbers of seedlings appeared only in the artificially created gaps (Table 5).

The numbers of both populations changed over the study period (Table 6). The populations were smallest in the year 
TABLE 2. Number of rosettes, generative shoots and area of 10 marked genets of Iris sibirica observed in experimental garden. The developmental stages: S. - seedlings; JUW. - juvenile; E. GEN. - early generative. * probability that average values for a given year do not differ from the average values for the previous year.

\begin{tabular}{|c|c|c|c|c|c|c|}
\hline \multirow{2}{*}{$\begin{array}{l}\text { Developmental } \\
\text { stage }\end{array}$} & \multirow{2}{*}{ Year } & \multirow{2}{*}{$\begin{array}{l}\text { Number } \\
\text { of genets }\end{array}$} & \multicolumn{2}{|c|}{ Number of ramets } & \multicolumn{2}{|c|}{ Genets' area $\left(\mathrm{cm}^{2}\right)$} \\
\hline & & & Average value & Range & Average value & Range \\
\hline S & 2000 & 10 & 1.0 & $1-1$ & 0.45 & $0.2-0.5$ \\
\hline JUW & 2001 & 10 & $4.7 * *$ & $3-6$ & $1.25^{* * *}$ & $1-1.5$ \\
\hline E.GEN & 2002 & 10 & $15.3^{* * * *}$ & $12-18$ & $8.67 * * *$ & $8-9.5$ \\
\hline
\end{tabular}

$* \mathrm{P} \leq 0,05 ; * * \mathrm{P}<0,01 ; * * * \mathrm{P}<0,001$

TABLE 3. Ramets number and area of 5 marked ramet clusters of Iris sibirica observed in natural sites. The developmental stages: GEN. - generative; SEN. - senile; FRAG. - fragmentation. * probability that average values for a given year do not differ from average values for the previous year.

\begin{tabular}{|c|c|c|c|c|c|c|}
\hline \multirow{2}{*}{$\begin{array}{l}\text { Developmental } \\
\text { stage }\end{array}$} & \multirow{2}{*}{ Site of observation } & \multirow{2}{*}{ Year } & \multicolumn{2}{|c|}{ Number of ramets } & \multicolumn{2}{|c|}{ Area of ramet clusters $\left(\mathrm{cm}^{2}\right)$} \\
\hline & & & Average value & Range & Average value & Range \\
\hline \multirow[t]{6}{*}{ GEN } & Opatkowice & 2000 & 90.4 & $68-111$ & 249.0 & $110-358$ \\
\hline & & 2001 & $118.8 * * *$ & $87-136$ & $384.2 * *$ & $182-447$ \\
\hline & & 2002 & $150.8 * * *$ & $117-169$ & $481.4 * * *$ & $241-530$ \\
\hline & Stanisławice & 2000 & 86.6 & $63-109$ & 216.2 & $132-306$ \\
\hline & & 2001 & $115.6^{* * * *}$ & $79-130$ & $269.0 *$ & $169-399$ \\
\hline & & 2002 & $142.2^{* * *}$ & $99-169$ & $321.2^{* *}$ & $191-483$ \\
\hline \multirow[t]{6}{*}{ SEN. } & Opatkowice & 2000 & 163.0 & $146-182$ & 789.8 & $775-820$ \\
\hline & & 2001 & $193.2 * * *$ & $168-216$ & $931.0 * * *$ & $912-950$ \\
\hline & & 2002 & $218.0 * * * *$ & $199-232$ & $1082.6^{* * *}$ & $1009-1116$ \\
\hline & Stanisławice & 2000 & 176.8 & $156-191$ & 766.2 & $650-809$ \\
\hline & & 2001 & $192.0 * *$ & $170-210$ & $860.6^{* * * *}$ & $733-936$ \\
\hline & & 2002 & $215.2 * *$ & $186-247$ & $937.2 * *$ & $793-998$ \\
\hline \multirow[t]{6}{*}{ FRAG. } & Opatkowice & 2000 & 231.2 & $218-253$ & 1278.2 & $1225-1398$ \\
\hline & & 2001 & $224.0 *$ & $213-247$ & $1306.0 *$ & $1236-1412$ \\
\hline & & 2002 & $216.6 * *$ & $206-235$ & $1327.4 * *$ & $1315-1447$ \\
\hline & Stanisławice & 2000 & 231.6 & $216-252$ & 1238.8 & $1059-1331$ \\
\hline & & 2001 & $220.0 * *$ & $210-243$ & $1256.8 * *$ & 1086-1346 \\
\hline & & 2002 & $213.6^{* * * *}$ & $204-237$ & $1274.6^{*}$ & 1093-1359 \\
\hline
\end{tabular}

$* \mathrm{P} \leq 0,05 ; * * \mathrm{P}<0,01 ; * * * \mathrm{P}<0,001$

2000 and higher in 2001. In Stanisławice, the recruitment of seedlings constituted only a minor contribution, whereas in the much smaller population in Opatkowice the 2001 increase was almost twofold. In 2002, the numbers increased slightly in both populations.

\section{DISCUSSION}

The absence of seedlings and young individuals observed in the first year of the studies indicates that, clonal reproduction is the principal mechanism underpinning the continuing existence of the Iris sibirica population in moor grass meadows. It was emphasised repeatedly, that vegetative propagation could assure the survival of populations of various species in newly colonised sites (Harper 1977; Abrahamson 1980; Van Groendael and de Kroon 1990; Soukupovà et al. 1994; Oborny and Podani 1996; Van Groendael et al. 1997; Eckert 2002). According to Klimeš (1997) and Klimeš and Klimešova (1999) Iris sibirica has a simi- lar pattern of vegetative reproduction as Iris pseudacorus, I. pumila, Filipendula ulmaria and F. rubra, involving slow proliferation and fragmentation of genets. The most intensive proliferation of individuals of these species occurs in the younger age stages. In this period, the numbers of ramets and individual areas increase remarkably. At later age stages, the effectiveness of vegetative reproduction gradually declines. In natural conditions, the unabated growth of individuals is occupied by neighbouring plants (Falińska 1986, 1995, 1997). Iris pseudacorus and Filipendula ulmaria proliferated most intensively in meadows, less intensively in macroforb communities, and even less in willow shrubs (Falińska 1986, 1995). The differences in the proliferation rates of the genets of Filipendula ulmaria were also noted in patches of meadows of different species compositions (Tamm et al. 2002). The observations of populations of Iris sibirica suggest that the proliferation of this species is different even within meadows of similar species composition, but with different dominant species. The prevalence of tall perennials displaying great competitive po- 


\begin{tabular}{|c|c|c|c|c|c|}
\hline$E$ & & \multicolumn{2}{|l|}{ D } & 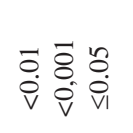 & 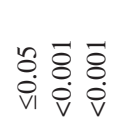 \\
\hline \multirow{8}{*}{ 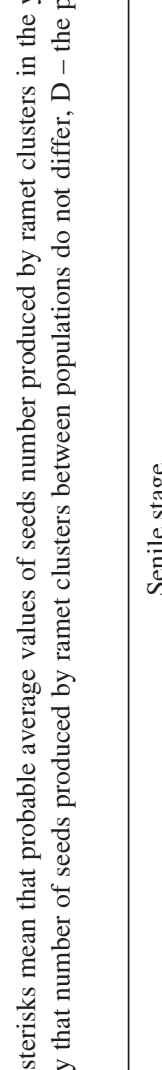 } & \multirow{8}{*}{ 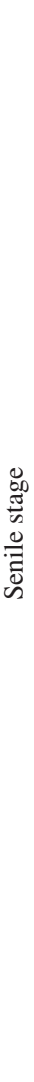 } & \multirow{3}{*}{ 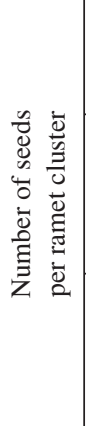 } & $u$ & 111 & 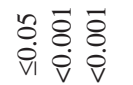 \\
\hline & & & $\infty$ & 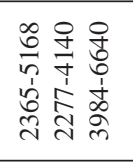 & 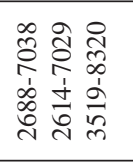 \\
\hline & & & $\varangle$ & 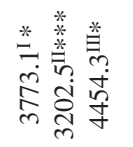 & 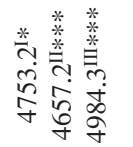 \\
\hline & & \multirow{2}{*}{ 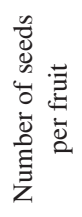 } & $\infty$ & 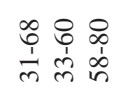 & 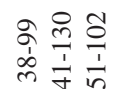 \\
\hline & & & $\varangle$ & 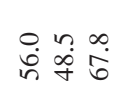 & 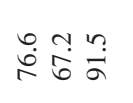 \\
\hline & & \multirow{2}{*}{ 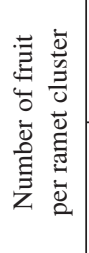 } & $\infty$ & 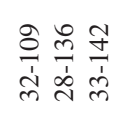 & 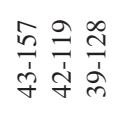 \\
\hline & & & $\varangle$ & 它客灾 & 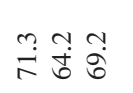 \\
\hline & & \multicolumn{2}{|c|}{ 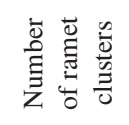 } & $a \sigma a$ & 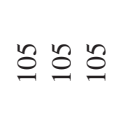 \\
\hline \multirow{10}{*}{ 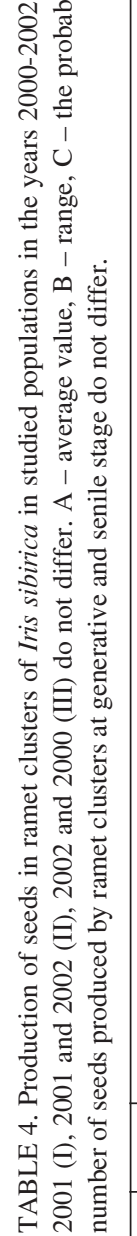 } & \multirow{5}{*}{\begin{tabular}{|l} 
\\
\\
\end{tabular}} & \multirow{3}{*}{ 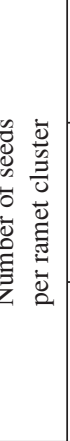 } & $u$ & 111 & 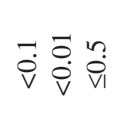 \\
\hline & & & $\infty$ & 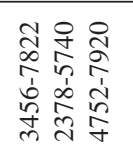 & 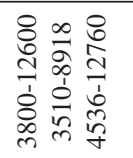 \\
\hline & & & $\varangle$ & 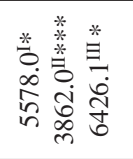 & 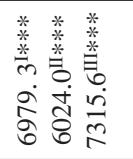 \\
\hline & & \multirow{2}{*}{ 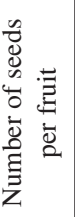 } & $\infty$ & 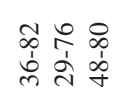 & 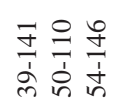 \\
\hline & & & $\varangle$ & $\begin{array}{l}0 \\
\dot{0} \\
\dot{b}\end{array}$ & 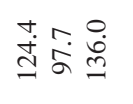 \\
\hline & \multirow{2}{*}{\multicolumn{2}{|c|}{ 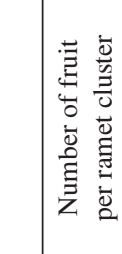 }} & $\infty$ & 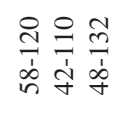 & 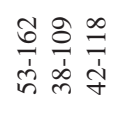 \\
\hline & & & $\varangle$ & 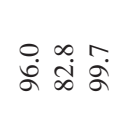 & 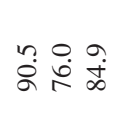 \\
\hline & & \multicolumn{2}{|c|}{ 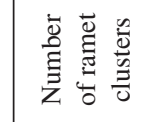 } & $\stackrel{\infty}{\sim} \stackrel{\infty}{\sim}$ & : đْ \\
\hline & \multicolumn{3}{|c|}{$\overbrace{\nu}^{\bar{d}}$} & 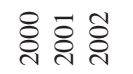 & 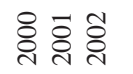 \\
\hline & \multicolumn{3}{|c|}{ К!!!вวоТ } & כ!моуцедо & UE?S \\
\hline
\end{tabular}

tential inhibits the proliferation of Iris sibirica, whereas the proximity of plants with low competitive potential exerts very little inhibitive effects.

Despite the prevalence of vegetative over generative reproduction, the clonal plants are characterised by high seed production. As with most species, in Iris sibirica, it is the mature plants which produce most seeds, while with ageing the production of seeds declines. The production of seeds also depends on the weather, particularly on temperature. The studies carried out on Iris pumila showed that the lower seed production resulted from the delay of flowering, whereas the increase in diaspore production resulted from earlier flower setting (Tarasjev 2005). In the light of these findings, the higher seed production in the populations of Iris sibirica in the years 2000 and 2002 could be explained by the earlier flowering time brought about by higher air temperatures. In 2000 and 2002 it started in the 2nd decade of May and lasted to the beginning of July, whereas in 2001 it occurred from the 3rd decade of May and ended in the 2nd decade of July (Kostrakiewicz 2006).

Despite of the significant fertility of individuals, the development of genets of Iris sibirica occurred not in a fully compact herb layer, regardless of neighbouring plants. It was found only in gaps created specially for this purpose. In result, the abundance in both populations increased and the age structure rejuvenated. Recruitment of seedlings in gaps only was observed also in Filipendula rubra and $F$. ulmaria (Aspinwall and Christian 1992; Falińska 1997; Kostrakiewicz 2003). The results of this study corroborate the data obtained by Borkowska (2004) in observations of the recruitment of clonal species seedlings in unmown meadows. She discovered that new genets appeared only in the artificially created gaps, which are the safest sites for germination, and regenerative niches as well. The role of such gaps in the recruitment of seedlings was also emphasised by authors studying xerothermic grasslands (Rusch 1992; Rusch and Fernández-Palacios 1995) or forest communities (Sydes and Grime 1981; Errikson 1995; Vellend et al. 2000; Dzwonko and Gawrońki 2001, 2002).

The performed observations confirmed that neighbourhood affects on mortality of Iris sibirica genets. Smalltussock species with low competitive ability enable a high survival of Iris sibirica seedlings, whereas tall perennial plants eliminate seedlings by shading them and by mechanical effect of the vegetable mass. It should be mentioned also that survival of seedlings of Iris sibirica was markedly higher than the survival rate of Iris pseudacorus and Filipendula ulmaria seedlings developing in artificially created gaps and in natural conditions (Falińska 1986, 1995). Performed observations confirm that species of low and high competitive ability did not accelerate the death of clusters of Iris sibirica ramets.

To sum up, neighbourhood of small-tussocks species or others with delicate, shallowly rooted underground organs, occupying small areas enabled the vegetative growth of Iris sibirica ramets clusters, ensuring them the occupation of space. The neighbourhood of species with minor competitive power favoured also the seedlings' survival and establishment of juvenile genets, leading to the increase of population abundance and its rejuvenation. On the contrary, tall herbs with robust underground organs occupying large areas inhibited the enlargement of Iris sibirica ramets clusters. Furthermore, species with great competitive abili- 
TABLE 5. Recruitment of seedlings in plots in a fully compact herb layer and in experimentally created gaps: 1-3 - number of plots in a fully compact herb layer; 4-6 - number of plots in experimentally created gaps.

\begin{tabular}{|c|c|c|c|c|c|c|c|c|c|}
\hline \multirow{3}{*}{ Population } & \multirow{3}{*}{ Plot } & \multicolumn{2}{|c|}{ Number of seeds } & \multicolumn{4}{|c|}{ Number of seedlings } & \multirow{2}{*}{\multicolumn{2}{|c|}{$\begin{array}{l}\text { Percentage of seedlings grown } \\
\text { in } 2001 \text { and } 2002\end{array}$}} \\
\hline & & \multirow{2}{*}{ Average value } & \multirow{2}{*}{ Range } & \multicolumn{2}{|c|}{2001} & \multicolumn{2}{|c|}{2002} & & \\
\hline & & & & Average value & Range & Average value & Range & Average value & Range \\
\hline \multirow[t]{2}{*}{ Opatkowice } & $1-3$ & 1105.3 & $943-1254$ & - & - & - & - & - & - \\
\hline & $4-6$ & 1836.3 & $1612-1973$ & 9.7 & $7-13$ & 1.0 & $1-2$ & 0.6 & $0.4-0.8$ \\
\hline \multirow[t]{2}{*}{ Stanisławice } & $1-3$ & 891.7 & $566-1263$ & - & - & - & - & - & - \\
\hline & $4-6$ & 1746.3 & $1645-1812$ & 8.3 & $5-13$ & 1.3 & $1-2$ & 0.5 & $0.4-0.7$ \\
\hline
\end{tabular}

TABLE 6. Number of genets and ramet clusters in different development stages in studied populations, involving seedlings germinated in experimental created gaps. The developmental stages: S. - seedlings; JUW. - juvenile; E. GEN. - early generative; GEN. - generative; SEN. - senile; FRAG. - fragmentation. The percentage of genets and ramet clusters at different developmental stages was set in brackets.

\begin{tabular}{|c|c|c|c|c|c|c|c|c|}
\hline & \multirow{2}{*}{ Year } & \multicolumn{6}{|c|}{ Developmental stages } & \multirow{2}{*}{$\begin{array}{l}\text { Number } \\
\text { of ramet } \\
\text { clusters }\end{array}$} \\
\hline & & $\mathrm{S}$ & $\mathrm{J}$ & E.GEN & GEN. & SEN & FRAG. & \\
\hline \multirow[t]{3}{*}{ Opatkowice } & 2000 & 0 & 0 & 0 & $13(50 \%)$ & $9(35 \%)$ & $4(15 \%)$ & 26 \\
\hline & 2001 & $29(53 \%)$ & 0 & 0 & $13(24 \%)$ & $9(16 \%)$ & $4(7 \%)$ & 55 \\
\hline & 2002 & $2(4 \%)$ & $23(45 \%)$ & 0 & $13(25 \%)$ & $9(18 \%)$ & $4(8 \%)$ & 51 \\
\hline \multirow[t]{3}{*}{ Stanisławice } & 2000 & 0 & 0 & 0 & $191(38 \%)$ & $206(41 \%)$ & $105(21 \%)$ & 502 \\
\hline & 2001 & $29(5 \%)$ & 0 & 0 & $191(36 \%)$ & $206(39 \%)$ & $105(20 \%)$ & 527 \\
\hline & 2002 & $4(1 \%)$ & $17(4 \%)$ & 0 & $191(36 \%)$ & $206(39 \%)$ & $105(20 \%)$ & 523 \\
\hline
\end{tabular}

ty speeded up the mortality of Iris sibirica seedlings, resulting in a lower increase of population numbers and its weaker rejuvenation. Simultaneously it should be marked that longer vegetative spread of species with low competitive power dominated in Opatkowice most probably will not lead to death of genets and clusters ramets of Iris sibirica, whereas the very expansive species prevailing in Stanisławice could eliminate them. The same phenomenon was recorded in populations of Iris pseudacorus, Filipendula ulmaria in thistle meadows, and meadows dominated by macroforbs and willows abandoned for 20 years (Falińska 2003).

The results of the presented study imply that vegetative propagation ensures the survival of the populations, but recruitment of seedlings allows an increase number and rejuvenation of the population. It was stressed repeatedly that even a small recruitment increases the genetic variability of the population and increases it chances of survival in a changing environment. This is particularly important for small populations endangered by extinction because of their too small gene pool. (Ellstrand and Roose 1987; Eriksson 1989, 1997; Widén et al. 1994; Lande 1988; Ellstrand and Elam 1993; Honnay and Bossuyt 2005). This point has also been confirmed in studies of many taxa nearing extinction, e.g. Cypripedium calceolus (Brzosko and Ratkiewicz, Wróblewska 2002; Brzosko et al. 2002), Ranunculus reptans (Fischer et al. 2000), Gentiana pneumonanthe (Krenova and Lěps 1996) and Silene spaldingii (Lesica 1999). The observations made in this study, allow to conclude that creating gaps which facilitatis the germination of seeds and development of seedlings, combined with the removal of expansive neighbours showing free proliferation of the ramet clusters of Iris sibirica is an effective measure of active protection of this species.

\section{CONCLUSIONS}

Six age stages were distinguished in the individual development of the Iris sibirica plants (Table 1, Figs 1-3). Vegetative proliferation in subsequent stages of development varied. The highest increase in number of above-ground units and the areas occupied by individuals occurred in the juvenile and early generative stages. In the generative, senile and fragmentation stages the proliferation declines gradually (Tables 2 and 3). In the community where species of high competitive potential dominate, the proliferation of the Iris sibirica clusters is less intensive, whereas it is greater in the community of species showing a lower competitive potential. Despite the significant level of seed production (Table 4), the increase in the number of genets resulted solely from the recruitment of seedlings in artificially created gaps (Table 5). The recruitment and development of seedlings in subsequent years contributed to the rejuvenation of population age structure (Table 6). On the basis of the observations made in this study, it may be concluded that creating gaps facilitating the germination of seeds and development of seedlings, combined with the removal of expansive neighbours containing a free proliferation of the ramet clusters of Iris sibirica, is an effective measure of active protection of this species.

\section{ACKNOWLEDGEMENTS}

I would like to express my considerable gratitude to Professor dr hab. Krystyna Falińska, for her valuable consultations during the course of these studies, and to Professor dr hab. Zbigniew Dzwonko for reading the manuscript, his suggestions and the help extended to me during the preparation of this paper. 


\section{LITERATURE CITED}

ABRAHAMSON W.G. 1980. Demography and vegetative reproduction. In: Demography and Evolution of Plant Populations. Solbrig O.T. (ed.) Blackwell, Oxford UK, pp. 89-106.

ASPINWALL N, CHRISTIAN T 1992. Clonal structure, genotypic diversity, and seed production in populations of Filipendula rubra (Rosaceae) from the northcentral United States. Am. J. Bot. 79 (3): 294-299

BARABASZ B. 1998. Chronione i zagrożone gatunki łąkowe w północnej części Puszczy Niepołomickiej. Fragm. Flor. Geobot. Ser. Polonica 5: 109-116. (in Polish with English summary)

BORKOWSKA L. 2004. The patterns of recruitment of clonal species seedlings in unmown meadow Cirsietum rivularis Ralski 1931. Experimental studies. Phytocenosis Vol. 16 (N.S) Archiv. Geobot. 10: 1-71.

BRZOSKO E. 2001. Changes in population structure of Carex cespitosa during 10 years of secondary succession in abandoned meadow in Białowieża. Ann. Bot. Fen. 38: 249-258.

BRZOSKO E., RRATKIEWICZ M., WRÓBLEWSKA A. 2002. Allozyme differentiation and genetic structure of the lady's slipper (Cypripedium calceolus) island populations in nort-east Poland. Bot. J. Linn. Soc. 138: 433-440.

BRZOSKO E., WRÓBLEWSKA A., RATKIEWICZ M. 2002. Spatial genetic structure and clonal diversity of island populations of lady's slipper (Cypripedium calceolus) from the Biebrza National Park (northeast Poland). Molec. Biol. 11: 2499$-2509$.

CAIN ML, DAMMAN H. 1997. Clonal growth and ramet performance in the woodland herb, Asarum canadense. J. Ecol. 85: 883-897.

CASWELL H. 1985. The evolutionary demography of clonal reproduction. In: Population biology and evolution of clonal organisms. Jackson J.B.C., Buss L.W., Cook R.E. (eds) Yale University Press, New Heven, pp. 187-224.

COOK R.E. 1983. Clonal plant populations. Amer. Sci. 71: 244$-253$.

CZARNECKA B. 1989. The effect of morphological-development proprieties of individual on spatial organization of $\mathrm{Ma}$ ianthemum bifolium (L.) F.W. Schmidt populations. Ekol. Pol 37 (1-2): 191-208.

DENISIUK Z. 1991. Interaction between agriculture and nature conservation in Poland. ICUN Press, Gland, Switzerland and Cambridge, UK. Vol. 12, pp. 1-162.

DENISIUK Z., KORZENIAK J., PŁECHA R. 1995. Meadows in Opatkowice near deserve protection. Chrońmy Przyr. Ojcz. 51 (4): 30-35. (in Polish)

DUBIEL E. 1991. Meadows in Cracov. Part I: Map of the actual vegetation of the city Cracow. Zesz. Nauk. UJ, Prace Bot. 958 (22); 121-133.

DUBIEL E. 1996. Meadows in Cracov. Studia Ośr. Dok. Fizjogr. PAN, 24: 145-171. Kraków. (in Polish)

DZWONKO Z., GAWROŃSKI S 2001. Effect of litter removal on species richness and acidification of a mixed oak-pine woodland. Biol. Conservation 106 (3): 389-398.

DZWONKO Z., GAWROŃSKI S 2002. Influence of litter and weather on seedling recruitment in a mixed oak-pine woodland. Ann. Bot. 90: 245-251.

ECKERT C.G. 2002. The loss of sex in clonal plants. Evol. Ecol. 15: 501-520.

ELLSTRAND N.C., ROOSE M.L. 1987 Patterns of genotypic diversity in clonal plant species. Am. J. Bot. 74: 123-131.

ERIKSSON O. 1989. Seedlings dynamics and life history in clonal plants. Oikos 55: 231-238.

ERIKSSON O. 1997. Clonal life histories and evolution of seed recruitment. In. The ecology and evolution of clonal plants. De Kron H. and Van Groenedael J. (eds) Bachuys Publishers. Leiden, pp. 211-226.
ERRIKSON O. 1995. Seedlings recruitment in deciduous forest herbs: the effect of litter, soil chemistry and seed bank. Flora 190: 65-70.

FALIŃSKA K. 1986. Demography of Iris pseudacorus L. populations in abandoned meadows. Ekol. Pol. 34 (4): 583-613.

FALIŃSKA K. 1995. Genet Disintegration in Filipendula-Ulmaria - Consequences for Population-Dynamics and Vegetation Succession. J. Ecol. 83 (1): 9-21.

FALIŃSKA K. 1997. Ekologia populacji. Podstawy teoretyczne, populacje, zbiorowiska, procesy PWN, Warszawa, p. 453.

FALIŃSKA K. 2003. Alternative pathways of succession: species turnover patterns in meadows abandoned for 30 years. Phytocenosis 15 (N.S) Archiv. Geobot. 9.

FALIŃSKA K., PIROŻNIKOW E. 1983. Ecological structure of Geranium robertianum L. populations under natural conditions and in the garden. Ekol. Pol.. 31 (1): 93-123.

FISHER M., HUSI R., PRATI D., PEITINGER M., VAN KLEUNEN M., SCHMID B. 2000. RAPD variation among and within small and large populations of the rare clonal plant $R a$ nunculus reptans (Ranunculaceae). Am. J. Bot. 87: 1128-1137.

HARPER J.L 1967. A Darwinian approach to plant ecology. J. Ecol. 55: 247-270.

HARPER J.L 1977. Population biology of plants. Academic Press NY.

HUNT R., HODGSON J.G., TOMPSON K., BUNGENER P., DUNNET N.P., ASKEW A.P. 2004. A new pratical tool for deriving a functional signature for herbaceus plant. Applied Veg. Sci. 7: 163-170.

KIRCHNER O. 1934. Lebensgeschichte der Blütenpflanzen Mitteleurapas.. Verlagsbuchhandlung Eugen Ulmer Stuttgart Band I Abt. 3 pp. 1168.

KLIMEŠ L., KLIMEŠOWA J., HENDRICS R., VAN GROENDAEL J. 1997. Clonal plant architecture: a comparative analysis of form and function. In. The ecology and evolution of clonal plants de Kroon and Van Groendael J. (eds) Blackhuys Publishers Leiden, pp. 1-29.

KLIMEŠ L., KLIMEŠOVA J. 1999. Database of clonal plants. http://www.butbn.cas.cz/klimes

KOSTRAKIEWICZ K. 2007. Seasonal rhythmicity of Iris sibirica (Iridaceae) population in Kostrze district of Kraków (S. Poland). Pol. Bot. Stud. 22: 311-316.

KOSTRAKIEWICZ K. 2001. Aktualny stan populacji kosaćca syberyjskiego Iris sibirica na wybranych stanowiskach w okolicach Krakowa. Chrońmy Przyr. Ojcz. 57 (4): 95-99. (in Polish)

KOSTRAKIEWICZ K. 2002. Aktualny stan populacji kosaćca syberyjskiego Iris sibirica na wybranych stanowiskach w okolicach Krakowa. Chrońmy Przyr. Ojcz.57 (4): 95-98. (in Polish)

KOSTRAKIEWICZ K. 2003 msk. Struktura i dynamika populacji Iris sibirica L. na łąkach trzęślicowych (Molinietum coeruleae) koło Krakowa. PhD thesis, Departament of Phytogeography and Taksonomy, Institute of Botany, Jagiellonian University Kraków (in Polish)

Ǩ̌ENOVA Z., LĚPS J. 1996. Regeneration of Gentiana pneumonanthe population in an oligotrophic wet meadow. J. Veget. Sci. 7: 107-112.

LAW R. 1981. The dynamics of colonizing population of Poa anпиа. Ecology 62: 1267-1277.

LESICA P. 1999. Effects of fire on the demography of the endangered, geophytic herb Silene spaldingii (Caryophylaceae). Am. J. Bot. 86: 996-1002.

LEZBERG AL, HALPERM CB, ANTOS JA. 2001. Clonal development of Maianthemum dilatatum in forests of differing age and structure. Can. J. Bot. 79: 1028-1038.

LANDE R. 1988. Genetics and demography in biological conservation. Science 241: 1455-1460.

ELLSTRAND NC, ELAM DR. 1993. Population genetic consequences of small population size: implications for plant conservation. Ann. Rev. Ecol. Syst. 24: 217-242. 
LOECHLE C. 1987. Partioning of reproductive effort in clonal plants: a benefit-cost model. Oikos 49 (2): 199-208.

LOUVETT-DOUST J. 1989 Plant reproductive strategies and ressource allocation. Trends Ecol. Evol. 4: 230-234.

ŁUKASIEWICZ A. 1966. Rytmika rozwojowa bylin (ze szczególnym uwzględnieniem organów podziemnych). PTPN Wydz. Mat.-Przyr. Prace Kom. Biol. 31 (5): 1-33. (in Polish)

OBORNY B., PODANI J. 1995. Clonality in plant communities. Abstr. Bot. 19: 1-127.

ROFF D.A. 1992. The Evolution of Life Histories. Chapman and Hall. New York USA

RUSCH G., FERNÁNDEZ-PALACIOS J.M. 1995. The influence of spatial heterogenity on regeneration by seed in a limestone grassland. J. Veg. Sci. 6: 417-426.

RUSCH G. 1992. Spatial pattern of seedling recruitment at two diffrent scales in a limestone grassland. Oikos 65 (3): 433-442.

SOUKUPOVÀ L.C, MARSCHALL T., HARA T., HERBEN T. (eds) 1994. Plant clonality: biology and diversity. Folia Geobot. Phytotax. 29: 113-320.

STEARNS S.C. 1989. Trade-off in life history evolution. Funct. Ecol. 3: 259-268.

STEARNS S.C. 1992. The evolution of life histories. Oxford Univ. Press., Oxford.

SYDES C., GRIME J.P. 1981. Effects of tree leaf litter on herbaceous vegetation in decidous woodland. I field investigations. J. Ecol. 68: 237-248.

SYMONIDES E. 1979a. The structure and population dynamics of psammophytes on inland dunes. I. Populations of initial stages. Ekol. Pol. 27 (1): 3-37.

SYMONIDES E. 1979b. The structure and population dynamics of psammophytes on inland dunes. II. Loosesod population. Ekol. Pol. 27 (2): 191-234.

SYMONIDES E. 1979c. The structure and population dynamics of psammophytes on inland dunes. III. Populations on compact psammophyte communities. Ekol. Pol. 27 (2): 325-257.

TAMM A., KULL K., SAMUEL M. 2002. Classyfing clonal growth forms based on vegetative mobility and ramet longevity: a whole community analysis. Evol. Ecol. 15: 383-401.
TARASJEV A. 2005. Impact of genet size and flowering on fruit set in Iris pumila L. Clones in wild. Acta Oecologica 27: 93-98.

VAN GROENDEAL H. and DE KROON H. (eds) 1990. Clonal growth in plant: regeneration and function. SPB Acad. Publishing the Hague, The Netherlands.

VAN GROENDEAL H.M., KLIMEŠ L. KLIMEŠOWA J. HENDRICS R. 1997. Comparative ecology of clonal plants. In: Plant life histories - Ecology, physiology and evolution. Silverrton J. Franco M., Harper J.L. (eds) Cambridge University Press, Cambridge, pp. 191-209.

VELLEND M., LECHOWICZ M.J., WATERWAY M.J. 2000. Germination end establishement of forests sedges (Carex, Cyperaceae): tests for home site advantage and effects of leaf litter. Am. J. Bot. 80 (10): 1517-1525.

WATKINSON A.R., DAVY A.J. 1985. Population biology of salt-marsch and sand-dune annuals. Vegetatio 62: 487-497.

WATKINSON A.R., HARPER J.L. 1978. The demography of a sand dune annual Vulpia fasciculata. I. The natural regulation of population. J. Ecol. 66: 15-33.

WIDÉN B, CRONBERG N., WIDÉN M. 1994. Genotypic diversity, molecular markers and spatial distribution of genets in clonal plants. In: Plant clonality, Biology and Diversity Soukupovà L, Marschal C, Hara T., Herben T. (eds) Oppulus Press Uppsala, pp. 139-157.

WILKON-MICHALSKA D. 1985. Struktura i dynamika populacji Salicornia patula Duvall-Jouvel. Rozpr. UMK 11-56. (in Polish)

ZAJĄC A., ZAJĄC M. (ed.) 1997. Distribution atlas of Vascular plants in Poland. Institute of Botany. Kraków.

ZARZYCKI K. 1956. O zachowanie wilgotnych łąk w Dolinie Górnej Wisły. Chrońmy Przyr. Ojcz. 12 (1): 11-17. (in Polish)

ZARZYCKI K. 1958. Wilgotne łąki w okolicach Czernichowa i potrzeba ich ochrony. Ochr. Przyr. 25: 49-68. (in Polish) 